\title{
Evaluation the Pollution of Sediments of the Shatt Al - Hillah with Heavy Metals by Using the Pollution Indices
}

\author{
Jwad k. Manii \\ Department of Geology, University of Babylon, Babylon, Iraq \\ sci.jwad.kadhum@uobabylon.edu.
}

Submission date:- 29/5/2018 Acceptance date:- 24/6/2018 Publication date:- 8/10/2018

Keywords: Trace elements; Sediment; Hilla river, Babylon, Pollution

\begin{abstract}
The level of pollutant of heavy metals ( $\mathrm{Hg}, \mathrm{Co}, \mathrm{Pb} \mathrm{V}, \mathrm{Cr}, \mathrm{Ni}, \mathrm{Sr}, \mathrm{Zr}, \mathrm{Mo}, \mathrm{Cu}, \mathrm{Rb}, \mathrm{Zn}, \mathrm{As}, \mathrm{Th}, \mathrm{U})$, in the sediment samples on the banks of the Shatt al-Hillah River The study was conducted in the Department of Earth Science at the collge of Science, University of Babylon, 14 samples of sediments ware collected from the banks of the river of Shatt Al-Hillah. The average concentration of the heavy metal in the sediment of the river bank in descending order: $\mathrm{Sr}$ (360.6 ppm) ,Cr (285.9 ppm), Ni (203.2 ppm), Co (169.9 ppm), Zr (166.3 ppm),. V (116.4ppm), Zn (91.6 ppm), Cu (48.8 ppm), Rb (41.9 ppm), Pb (18.1 ppm),As(11.1 ppm), Hg(5.7ppm),Th (4.2 ppm),Mo(3.7 ppm), U(2ppm,. The geoaccumulation index (Igeo) for $\mathrm{Hg}$ of five sampling station along the river was greater than 3.0, which indicate cotamination of sedimentation with a high degree of pollution. The Igeo for $\mathrm{Ni}$ in 11 sampling station and CO in 12 sites were greater than 1.0, indicated moderatly level of polluted sediment. The value of the pollution load index (PLI) for the total sampling stations ranged from $0.7-1.4$.
\end{abstract}

\section{1-Introduction}

1-1 Sediments in aquatic environments.

Heavy elements - Heavy elements exist in nature, where they go through the geochemical cycles to the environment. The high concentrations of heavy elements in the aquatic environment are dangerous to living organisms due to the ability of these organisms to accumulate these elements in their bodies and concentration which may cause imbalance in their vital functions[1]. The transmission of these elements through the food chains of humans, causing him many health damage. Heavy elements are defined as those that are five times the density of water $5 \mathrm{mg} / \mathrm{cm} 3$ cubic and have negative effects on the environment because of excessive use and affect the health of humans, animals and plants[2]. The increase in concentrations of toxic heavy metals in sediments may lead to increased level of these components in the aquatic organisms. This increase is cumulatively cumulative and hence the introduction of food through the human chain of food, thus causing health problems. As a result of various industrial and agricultural activities, These elements in the environment are the result of various activities and practices, including the waste disposal or sedimentation from the atmosphere, or excessive use of fertilizer and pesticides[3]. 
1-2- Aims of study: The main objective of this research is to demonstrate the rate of concentrations of heavy elements in sediments in the Shatt al-Hillah. This study can be considered attempt to evaluate the degree of contamination of the sediment of shat $\mathrm{Al}$ hilla river by the heavy elements harmful to the by using different indices like geoaccumulation index and pollution load index .

\section{1-3Location and area description:}

The studied area is the Babylon Governorate, it's located within the Mesopotamian plain, middle of Iraq, 100km away from Baghdad in the south, between Longitude (44 $50^{\prime} 36.62^{\prime \prime} \& 44^{0} 44^{\prime} 11.10^{\prime \prime}$ E) and Latitude $\left(32^{0} 13^{\prime} 46.05^{\prime \prime} \&\right.$ $32^{0} 27^{\prime} 46.72 \mathrm{~N}$ ), covering an area of about $5119 \mathrm{~km}$.

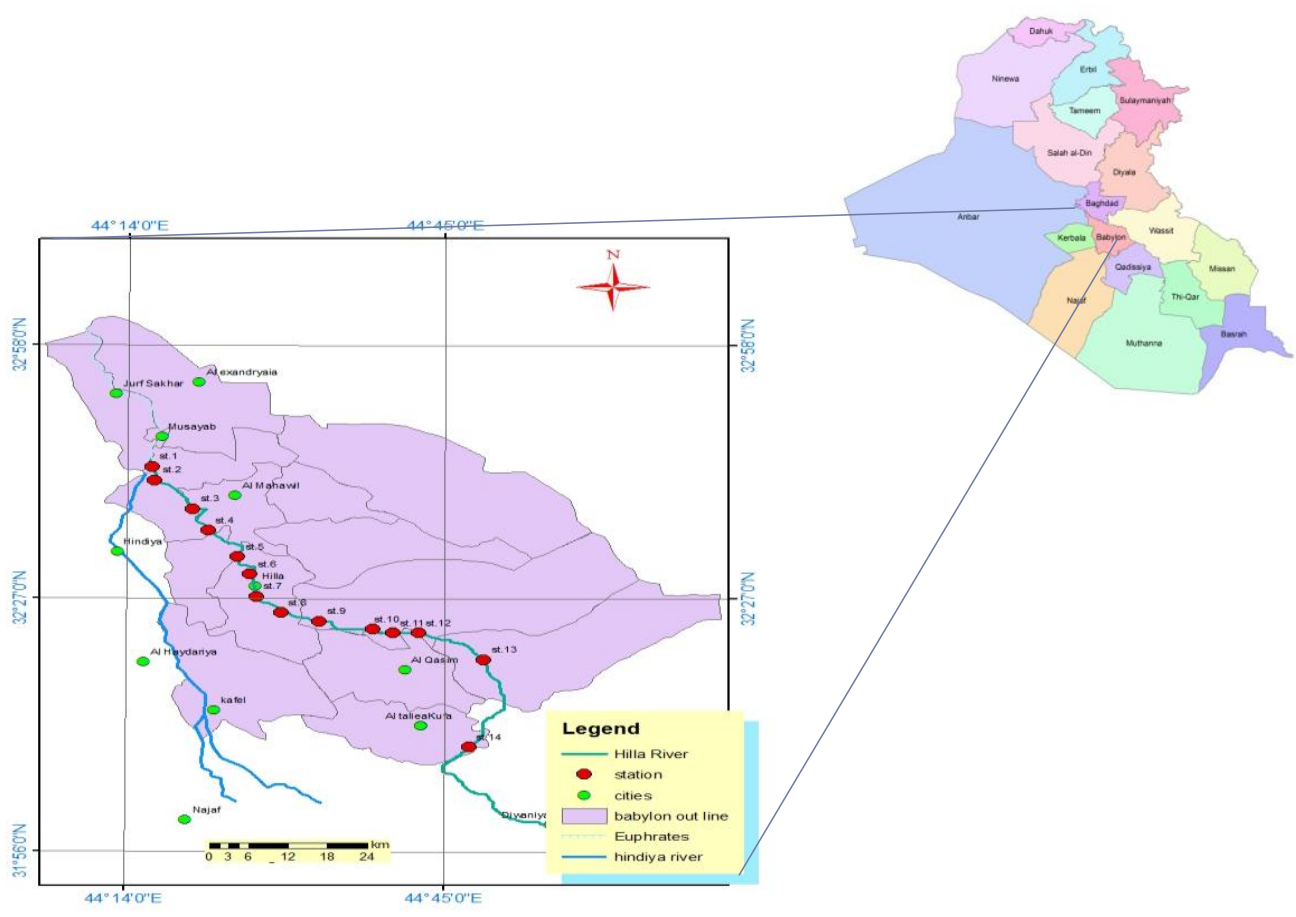

Figure (1) Map showing the Shatt al Hilla river catchment, the largest towns, and the station of sediment samples.

\section{2- Physiography:}

The Republic of Iraq divided into five broad physiography regions. each region has its specific geological hydrological and climatological condition and consequently specific soil condition as well. The study area located within the lower Mesopotamian plan is the southern part of an extensive geosyncline which at basin is wide and has a base of about $3 \mathrm{~km}$ below the surface filled with sediments from the older shelf sediments, river sediments form the upper part of these sediments[5].

\section{3-Geologic setting}

The study area is within the sedimentary plain in the unstable pavement area in relation to the tectonic division of Iraq [6]. This range, also called the Mesopotamian zone, is located within the geosyncline basin between the Zagros Mountains in the north-east and the stable Arab plateau in the south-west [7]. The area of research generally covers modern Quaternary sediments with the Pleistocene and Holocene sediments of the Flood Plain Deposit of the Euphrates [8]. There are also fill deposits. These deposits are caused by floods and are generally made up of thin layers of fine sand, and mud. [9] and Aeolian deposition are found in the eastern parts of the province. Dry marsh deposits are found in different areas of the study areas [10]. Sediments, which are the result of human activity, Remains of ancient canals 
and small archaeological tails representing ancient population settlements have long been characterised by natural phenomena as well as important geomorphological phenomena in the flatlands of the sedimentary plain [11].

\section{4-Topography and geomorphology of the region}

Babylon Governorate is located within the Sedimentary Plain, which is characterised by flatness, and low general slope. The slope is about $22 \mathrm{~cm}$ per kilometre and there are secondary slopes [10], where the land descends from the northern and western sides towards the eastern and southeastern parts. Some dunes are found in some areas, such as south of Hilla. These dunes have fixed bases, but their peaks are moving. Winds form shapes according to their direction [12].

\section{5- Hydrology of the area}

The province of Babel is characterised by the abundance of its streams that extend to its most agricultural areas. The Euphrates River and the branching streams are considered the main water resource of the study area. When the Euphrates River enters the province of Babylon, it is close to the Tigris River, The Euphrates River is about 7 meters high [12] This phenomenon has been exploited as the stream of the rivers of Yusufiya, Latifiya and Musayyib were opened to take their water from the Euphrates River. The river then branches south of Musayyib into two branches: Shatt al-Hindiy in the west and Shatt al-Hillah in the east. The Hindiya Barrage was established to raise water for the streams in front of it.Shatt al-Hillah is an important water resource in the province, where it passes through large areas, and it is divided into several rivers that feed and irrigate large agricultural lands [12].

\section{6- Shat al Hilla river}

As for the geographical location of Shatt al-Hillah, it is located in the center of Babylon province. It has a length of about $104 \mathrm{~km}$ within the province of Babyilon and the rate of width of a section in most of its parts is about 50 meters and irrigates an area of 2,365,000 dunums of agricultural land and passes through a number of districts, and the center of the province of Hilla and the Hashemiya, Shomali and even the province of Qadisiyah, where it branches into three branches are Dagara, Al huriya and Diwaniyah. Al Hilla is a city located in central Iraq on the banks of the Shatt alHillah River, which branches from the Euphrates river at the edge of Hindya, about 100 kilometers south of Baghdad. This city is the center of the province of Babylon and the largest cities of the province is also close to the historic city of Babylon and also close to the cities of Bursibba and Kish, which is a dense agricultural area Palm trees [13].

\section{7-Methodology}

Fourteen samples from the sediment banks of Shat al Hilla river were collected between December 2015 and January 2016. The samples are distributed through the fourteen station of the river (Fig. 1). All samples were dried in the oven with $60^{\circ} \mathrm{C}$, stone, plants and other impurity materials were removed from the samples, and the remaining sediment samples were powdered into $0.075 \mathrm{~mm}$. 15 trace element $(\mathrm{Pb}, \mathrm{V}, \mathrm{Cr}, \mathrm{Cu}, \mathrm{Rb}, \mathrm{Zr}, \mathrm{Co}, \mathrm{Ni}, \mathrm{Th}, \mathrm{Mo}, \mathrm{As}, \mathrm{Hg}, \mathrm{Sr}$, $\mathrm{Zn}, \mathrm{U}$ ) concentrations were determined in all samples by using X-ray fluorescence in the Geology department, colloge of science, university of Babylon, this technic the devise used in the analysis is Niton XRF analyzer.The concentrations of heavy elements in the sediments of the Shatt al-Hillah banks have been obtained and various indicators and guidelines have been applied to assess their pollution and environmental hazards. The total concentrations of heavy metals in the surface sediments of) Shatt al-Hillah were obtained and multiple indices and guidelines were applied to assess their contamination and ecological Hazared.

\section{8-Result and discussion}

The total concentration of heavy elements and the spatial distribution of these concentrations and the related information is summarized in Table 1. Based on the average concentrations, the target. 
Table 1. concentration, Average and range values of total heavy metal content (ppm) of all sampling sites.

\begin{tabular}{|c|c|c|c|c|c|c|c|c|c|c|c|c|c|c|c|}
\hline $\begin{array}{l}\text { Station } \\
\text { No }\end{array}$ & Co & $\mathrm{Ni}$ & $\mathrm{Cu}$ & $\mathrm{Zn}$ & Th & $\mathrm{Pb}$ & MO & $\mathrm{Zr}$ & $\mathrm{Sr}$ & $\mathrm{Rb}$ & As & $\mathrm{Cr}$ & $\mathrm{V}$ & $\mathrm{Hg}$ & $\mathrm{U}$ \\
\hline st.1 & 156 & 219 & 41 & 79 & 5 & 16 & 3 & 135 & 318 & 46 & 10 & 320 & 58 & 5 & nd \\
\hline st. 2 & 85 & 214 & 35 & 68 & 3 & 12 & 3 & 130 & 422 & 44 & 13 & 251 & 217 & 12 & nd \\
\hline st.3 & nd & nd & 41 & 75 & 4 & 19 & nd & 136 & 344 & 47 & 10 & 262 & 109 & $\mathrm{nd}$ & nd \\
\hline st.4 & 136 & 184 & 41 & 75 & 4 & 13 & 4 & 130 & 350 & 41 & 11 & nd & nd & 1 & nd \\
\hline st.5 & 204 & 215 & 55 & 81 & 5 & 12 & 5 & 109 & 331 & 47 & 14 & nd & nd & 4 & 4 \\
\hline st.6 & 171 & 207 & 37 & 84 & 3 & 16 & 3 & 158 & 351 & 41 & 10 & 436 & 38 & 5 & nd \\
\hline st.7 & 160 & 212 & 40 & 75 & 4 & 12 & 3 & 149 & 362 & 40 & 11 & 215 & 116 & 8 & 1 \\
\hline st.8 & 145 & 181 & 39 & 76 & 5 & 17 & 1 & 144 & 356 & 40 & 9 & 233 & nd & 1 & nd \\
\hline st.9 & 208 & 223 & 28 & 68 & 4 & 12 & 4 & 124 & 361 & 40 & 11 & 224 & 239 & 6 & nd \\
\hline st.10 & 128 & 181 & 109 & 185 & 4 & 42 & 4 & 171 & 419 & 39 & 12 & 353 & nd & nd & nd \\
\hline st.11 & 302 & 215 & 46 & 103 & 4 & 20 & 7 & 365 & 334 & 36 & 13 & nd & 1 & 8 & nd \\
\hline st.12 & 138 & 207 & 43 & 75 & 5 & 11 & 4 & 133 & 379 & 43 & nd & 267 & 141 & 3 & 1 \\
\hline st.13 & 160 & 203 & 40 & 85 & 5 & 17 & nd & 158 & 352 & 41 & 9 & 483 & 126 & 8 & 2 \\
\hline st.14 & 169 & 183 & 48 & 84 & 4 & 18 & 3 & 145 & 350 & 43 & 10 & 95 & 112 & 6 & nd \\
\hline Min & 85 & 181 & 28 & 68 & 3 & 11 & 1 & 109 & 318 & 36 & 9 & 95 & 1 & 1 & 1 \\
\hline Max & 302 & 223 & 109 & 185 & 5 & 42 & 7 & 365 & 422 & 47 & 14 & 483 & 239 & 12 & 4 \\
\hline Average & 169.9 & 203.2 & 48.8 & 91.6 & 4.2 & 18.1 & 3.7 & 166.3 & 360.6 & 41.9 & 11.1 & 285.9 & 116.4 & 5.7 & 2.2 \\
\hline
\end{tabular}


Table ( 2) Classification of sediments with regard to Igeo [4]

\begin{tabular}{|c|c|c|}
\hline Igeo & Class & Pollution intensity \\
\hline$>5$ & 6 & Very strong polluted \\
\hline $4-5$ & 5 & Strong to very strong \\
\hline $3-4$ & 4 & Strongly polluted \\
\hline $2-3$ & 3 & Moderately to strongly \\
\hline $1-2$ & 2 & Mnoderately polluted \\
\hline $0-1$ & 1 & Unpolluted \\
\hline$<0$ & 0 & Unolled to mod. polluted \\
\hline
\end{tabular}

Table 3. Pearson correlation matrix for the sediment components.

\begin{tabular}{|c|c|c|c|c|c|c|c|c|c|c|c|c|c|c|c|}
\hline & Co & $\mathrm{Ni}$ & $\mathrm{Cu}$ & $\mathrm{Zn}$ & Th & $P b$ & $M O$ & $Z r$ & $\mathrm{Sr}$ & $R b$ & As & $\mathrm{Cr}$ & $V$ & $\mathrm{Hg}$ & $U$ \\
\hline Co & 1 & & & & & & & & & & & & & & \\
\hline $\mathrm{Ni}$ & 0.7156 & 1 & & & & & & & & & & & & & \\
\hline $\mathrm{Cu}$ & -0.0382 & -0.052 & 1. & & & & & & & & & & & & \\
\hline $\mathrm{Zn}$ & 0.07665 & -0.0012 & 0.9544 & 1 & & & & & & & & & & & \\
\hline Th & 0.1382 & 0.07303 & 0.0471 & -0.0592 & 1 & & & & & & & & & & \\
\hline $\mathrm{Pb}$ & -0.082 & -0.2065 & 0.89788 & 0.95849 & -0.0815 & 1 & & & & & & & & & \\
\hline MO & 0.70619 & 0.53575 & 0.2184 & 0.23787 & -0.1425 & 0.03226 & 1 & & & & & & & & \\
\hline $\mathrm{Zr}$ & 0.59602 & 0.11608 & 0.12018 & 0.31082 & -0.1375 & 0.28095 & 0.49753 & 1 & & & & & & & \\
\hline $\mathrm{Rb}$ & -0.5681 & -0.3811 & -0.1636 & -0.3783 & 0.20713 & -0.3153 & -0.3476 & -0.6527 & -0.2038 & 1 & & & & & \\
\hline As & 0.20537 & 0.0443 & 0.17352 & 0.19945 & -0.387 & 0.20899 & 0.23021 & 0.21152 & -0.0566 & -0.0729 & 1 & & & & \\
\hline $\mathrm{Cr}$ & -0.3653 & -0.0573 & 0.06255 & 0.16978 & -0.0404 & 0.24652 & -0.6132 & -0.2463 & 0.28877 & 0.02066 & -0.3256 & 1 & & & \\
\hline V & -0.2478 & 0.03107 & -0.4623 & -0.4379 & -0.2392 & -0.4076 & -0.2438 & -0.3281 & 0.34134 & 0.17229 & -0.2201 & 0.28257 & 1 & & \\
\hline $\mathrm{Hg}$ & 0.34327 & 0.52442 & -0.422 & -0.3347 & -0.3204 & -0.4078 & 0.16646 & 0.22899 & 0.11499 & -0.129 & 0.24609 & 0.04231 & 0.53405 & 1 & \\
\hline$U$ & 0.19798 & 0.20522 & 0.05392 & -0.1103 & 0.50216 & -0.2588 & 0.06579 & -0.2307 & -0.2331 & 0.35443 & 0.06596 & -0.1489 & -0.1235 & 0.08808 & 1 \\
\hline
\end{tabular}

To assess the extent to which elements are enriched in environmental samples a geochemical methods are used by comparing the concentration of the element in the sample with its concentration in the continental crust, which is called the "the clarkevalues" relative to the American geologist Clark[14]. Another method used to determine the average composition of the upper crust is by measuring the concentrations of elements in soft granules. The most common of these formulas is the average values of the shale as reported and published by by [15].

Geoaccumulation index (Igeo). Igeo is contamination index which isWhich can be represented by the following equation : Ige $\mathrm{o}=\log 2 \frac{\mathrm{Ce}}{1.5 \mathrm{~GB}}$ (1)

where: Ce - concentration of the element in the sample GB - geochemical background concentration According to Igeo values, there are 7 classes of the sample pollution, varying from 0 (unpolluted) to 6 (extremely polluted). 
Table (2) and figure (3) presents the geo-accumulation index for the quantification of heavy metal accumulation in the study area. The I-geo grades for the study area sediments varies from metal to metal and site to site (across metals and sites). The values of all metal are zero or PLI $<0$ Un polluted PLI $=1$ Perfection PLI $>1$ Deterioration of the environment.

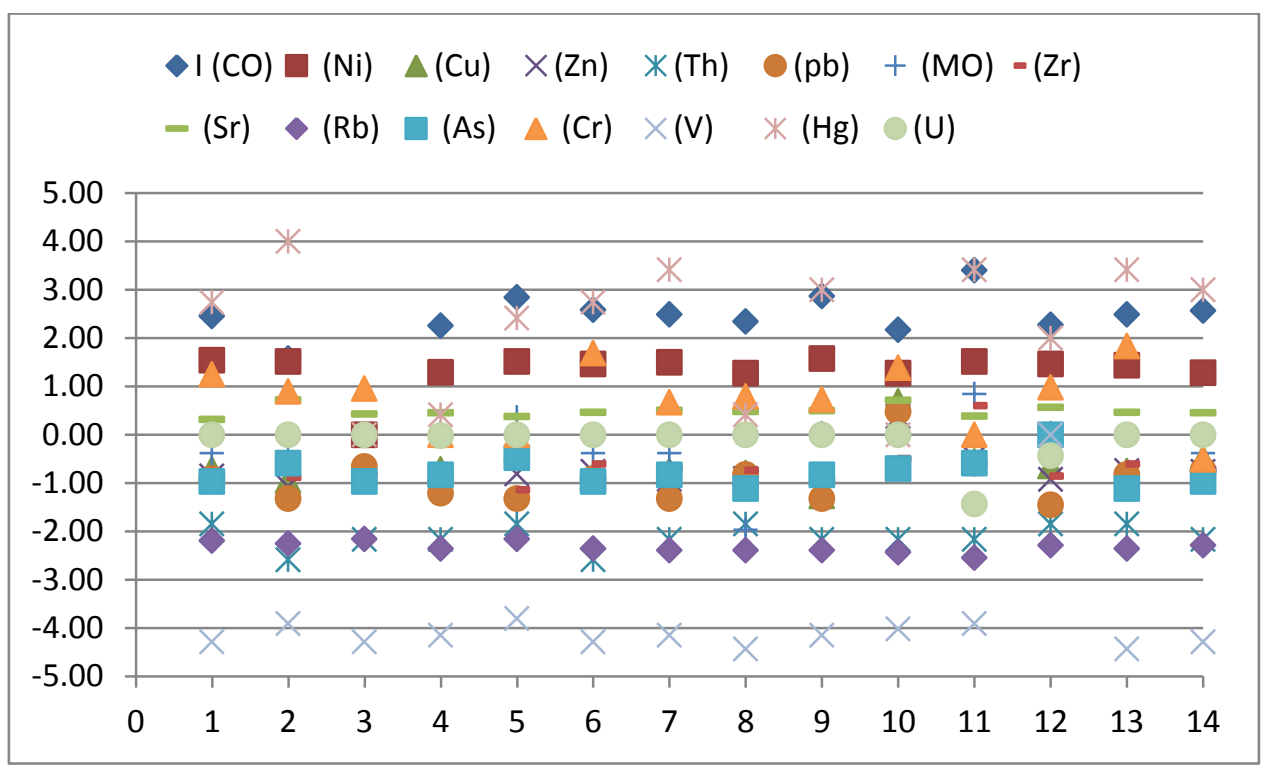

Fig. 2. Geoaccumulation index (Igeo) values of different sampling sites of shat al Hilla river

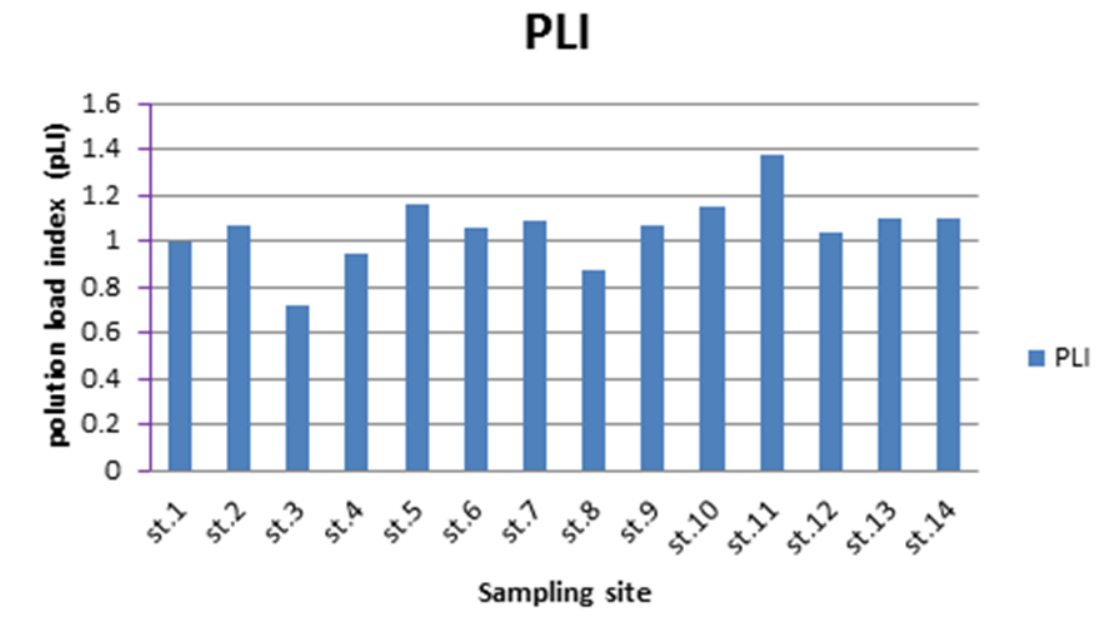

Fig. 3: PLI vs. sampling station 
Close to zero (unpolluted) expect the values for the nickel element ranged from 1 to 2 in all sites (Igeo class: 2), the values of mercury, the values reached 4 in station 3 while the values 3 were in stations $(8,12,14)$ moderately to strongly polluted.

\section{0- Pollution load index}

Determine the magnitude of heavy metal contamination in the sediment, the Pollution Load Index (PLI) and geoaccumulation Index (Igeo) were employed. Pollution load index (PLI) for each station were evaluated using the procedure of[16].

$$
\text { PLI }=(\text { CF1 x CF2 x CF3x.............Fn) 1/n (1) Where: } \mathrm{n}=\text { number of metals--------(2) }
$$

$\mathrm{CF}=$ contamination factor $\mathrm{CF}=$ Metal concentration in sediment/Background values of the metal PLI is a potent tool in heavy metal pollution evaluation. According to [16]

pollution load Index PLI provides simple but comparative means for assessing a site quality, where a value of PLI $<1$ denote perfection; PLI $=1$ present that only baseline levels of pollutants are present and PLI > 1 would indicate deterioration of site quality [17]. and coordination of PLI against sampling sites is expressed by Fig. 3 . in this study Calculation showed that (PLI) range is $0.72-1.38$ with a mean value of 1.1 indicating that the concerned heavy metals lie on the class PLI $=1$ the pollutants are present within the baseline level of pollutant are present.

Statistical methods were applied to process the analytical data in terms of the distribution and correlation among the studied parameters. Pearson's correlation coefficient analysis was performed to identify the relationship among heavy metals in sediments and their possible sources. The correlation matrix for the parameters studied was shown in Table 3. sum metals were significantly correlated with each other in the surface sediments of the shatt al Hilla river there is high positive correlation with a very significant probability) was observed between $\mathrm{Cu} / \mathrm{pb}, \mathrm{Pb} / \mathrm{zn}, \mathrm{Co} / \mathrm{Ni}, \mathrm{Co} / \mathrm{Mo}, \mathrm{Ni} / \mathrm{Hg}$, and $\mathrm{V} / \mathrm{Hg}$.

\section{1-Conclusion}

Geoaccumulation index (Igeo) showed that sediments of Shat al hilla river values for $\mathrm{Cu}, \mathrm{Zn}, \mathrm{Th}, \mathrm{Mo}, \mathrm{Pb}, \mathrm{Zr}, \mathrm{Sr}, \mathrm{U}, \mathrm{Th}, \mathrm{V}$, and As concentrations that were within the background values, sediment polluted by $\mathrm{Hg}$ was more widespread than the other heavy metals, which was contributed mostly by both natural and anthropogenic sources. The PLI values of all the sediment samples of the studied region that concerned heavy metals lie on the class $\mathrm{PLI}=1$ the pollutants are present within the baseline level of pollutant are present. 


\section{CONFLICT OF INTERESTS}

\section{There are no conflicts of interest.}

\section{2-References}

[1] M.K. Ahmed. An assessment at trace metal pollution in coastal area of Bangladesh. Otsu chi Mar. Sci. 26 : 73. 2001.

[2] V. Mary Kensa. Accumulation of Heavy Metals in Colachel estuarine sediments, KanyakumariDistrict, Tamil Nadu, India, Jr. of Industrial Pollution Control 28(1) pp 83-86. 2012.

[3]United Nations Human Settlement Program. 2008.

[4] I. Legorburu, J.G. Rodríguez, Á.Borja, I. Menchaca, O. Solaun, V.Valencia, I. Galparsoro, and J. Larreta, Source characterization and spatio-temporal. 2013.

[5] P. Buring. Soils and Soil Conditions of Iraq. Ministry of Agriculture-Directorate General of Agricultural Research and Projects, Baghdad 322pp. 1960.

[6]- T. Buday. The Regional Geology of Iraq: Stratigraphy and Paleogeography. State Organization for Minerals, Baghdad 445pp. 1980.

[7] J.K. Manii .’Using GIS to Study the Probability Pollution of Surface Soil in Babylon Province, Iraq".Journal of Applied Geology and Geophysics. 2:14-18. 2014.

[8]- V.K. Sissakian, editor. Geological map f iraq ,central company of geological survey and meneralization ,GEOSURF. 2000.

[9]- R.M.Parsone. "Ground water resources of Iraq". Mesopotamian plain .Ministry of Development, Development Board ,Baghdad vol. 11,157p. 1957.

[10]-Al-Jabouri. The geotectonic evaluation for the soil in the Babylon Governorates. Thesis, Collage of science University of Baghdad,In Arabic:183. 2002.

[11]-Berwari, Anwar Mustafa, Saliwa, Nasira Aziz. Report on the Geology of the Karbala Plate, General Company for Geological Survey and Mining, Baghdad, Iraq. 1995.

[12] Al-Jabouri.The geotectonic evaluation for the soil in the Babylon Governorates. Thesis, Collage of science University of Baghdad,In Arabic:183. 2002

[13] A. J.D. Al-Saadoun. Study the tourist reality of the province of Babylon, the need to plan tourism services,Master thesis, Baghdad University, the Center of planning and regional archaeological 144 pp. 1988.

[14]- J.K. Manii .Hydrochemistry of the ground water and its relationship with the mineral of open aqufer sediment in selected location within babylon governorate ,Master thesis. 2003

[15]- R.L.Rudnick, \& S.Gao. The Composition of the Continental Crust. In: H. D. Holland \& K. K. Turekian. (Eds.) Treatise on Geochemistry. Vol. 3 (pp. 1-64). Oxford: Elsevier-Pergamon. 2003.

[16]- K. K. Turekian, \& K. H. Wedepohl, Distribution of the elements in some major units of the earth's crust. Geological Society of America Bulletin, 72, 175-191. 1961.

[17]- D. L.Tomlinson, J. G. Wilson, C. R. Harris \& D. W. Jeffrey . "Problems in the assessments of heavy metal levels in estuaries and formation of a pollution index". Helgol Meeresunters, 33, 566-575. 1980 


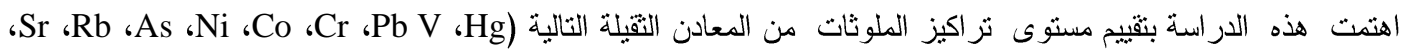

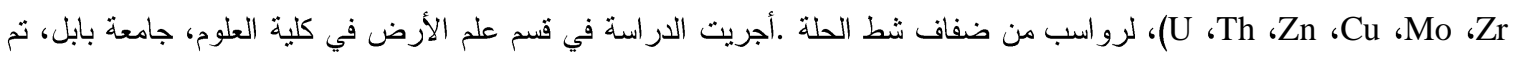

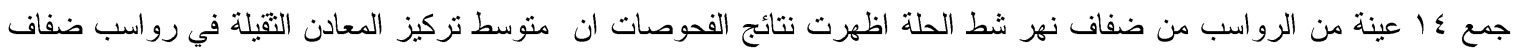

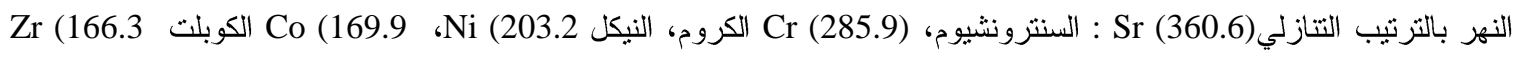

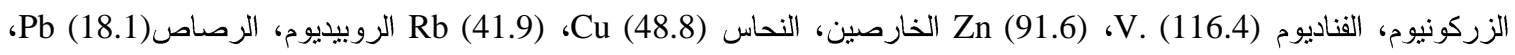

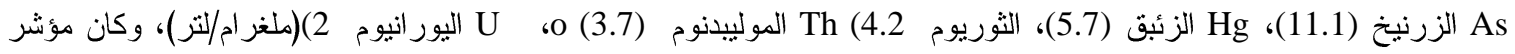

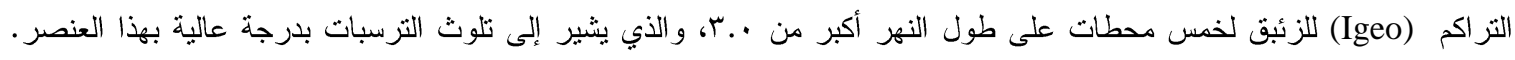

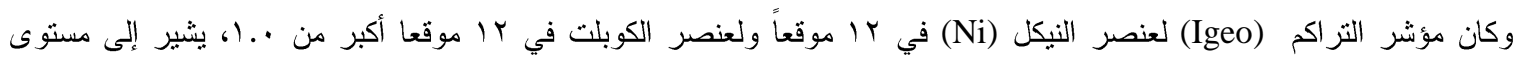

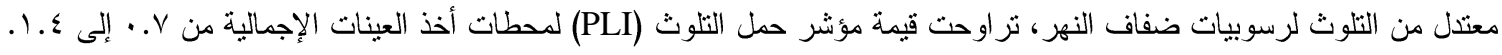
الكلمات الدالة: أثز العناصر، الرواسب. نهر الحلة، بابل، التلوث. 